\title{
STATE TAXATION OF BANKRUPTCY LIQUIDATIONS: FEDERALISM MISCONCEIVED*
}

ONCE viewed as immune property within the custody of the federal sovereign, ${ }^{1}$ a bankrupt's estate is now generally subject to the same state and local taxes as are the property and activities of an individual. ${ }^{2}$ Judicial recognition that government services subsidized by state property taxes were ratably extended to property in the hands of the bankruptcy trustee engendered the initial inroad on this immunity. ${ }^{3}$ Subsequent federal legislation relegates agents or officers conducting businesses by authority of United States courts to the status of private parties for purposes of taxation. ${ }^{4}$ However, some courts have denied the imposition of state and local taxes on trustee-conducted liquidation sales. ${ }^{5}$ Holding the waiver statute inapplicable, they have asserted that allowing such taxes might interfere with Congress's paramount authority over bankruptcy by burdening the court process through which that authority is exercised. ${ }^{6}$

*California State Bd. of Equalization v. Goggin, 245 F.2d 44 (9th Cir.), cert. dentied, 353 U.S. 961 (1957).

1. In re Mason Tire \& Rubber Co., 39 F.2d 462, 465 (N.D. Ohio 1930) ; 3 Collner, BANKRUPTCY $\llbracket$ 62.14, at 1509 (14th ed. 1956). Interference with property held in custodia legis was apparently viewed as a violation of a sovereign's supreme political authority. See Hagan v. Lucas, 35 U.S. (10 Pet.) 263 (1836) (invalidating levy by federal marshal on property which had been placed in custody of law by prior levy of state sheriff); cf. 2 COOLEY, TAXation $\$ 554$ (4th ed. 1924).

2. Michigan v. Michigan Trust Co., 286 U.S. 334 (1932) (state corporate franchise tax); In re Sims, 118 Fed. 356 (W.D. Ga. 1902) (state property tax); In re Conhaim, 100 Fed. 268 (D. Wash. 1900) (state property tax); 3 Collier, Bankruptcy $\{62.14$, at 1509 (14th ed. 1956); 2 COOLEY, TAXation $\S 555$ (4th ed. 1924); see Goggin v. Byram, 172 F.2d 868 (9th Cir. 1949) (county property tax); 28 U.S.C. $\$ 960$ (1952), note 4 infra.

3. Swarts v. Hammer, 194 U.S. 441,444 (1904). This rationale is particularly applicable to merchandising concerns with large inventory stocks requiring significant police and fire protection.

4. "Any officers and agents conducting any business under authority of a United States court shall be subject to all Federal, State, and local taxes applicable to such business to the same extent as if it were conducted by an individual or corporation." 62 STAT. 927 (1948), 28 U.S.C. \& 960 (1952), amending 48 STAT. 993 (1934); see note 36 infra and accompanying text; text at note 37 infra. The 1934 act was passed in response to a district court ruling that a federal receiver operating a gasoline distributing business was not liable for a state sales tax on motor fuel. See Howe v. Atlantic, Pac. \& Gulf Oil Co., 4 F. Supp. 162 (W.D. Mo. 1933) (common-law immunity of trustee not affected by generally worded state taxing statute), rev'd sub som. Kansas City v. Johnson, 70 F.2d 360 (8th Cir.), cert. denied, 293 U.S. 617 (1934). Congress intended the statute to preclude significant loss of state revenue. H.R. REP. No. 1138, 73d Cong., 2d Sess. (1934); S. REP. No. 1372, 73d Cong., 2d Sess. (1934).

5. California State Bd. of Equalization v. Goggin, 191 F.2d 726 (9th Cir. 1951) (state sales tax); State Bd. of Equalization v. Boteler, 131 F.2d 386 (9th Cir. 1942) (same); In re West Coast Cabinet Works, Inc., 92 F. Supp. 636 (S.D. Cal. 1950) (same).

6. U.S. Const. art. I, \& \&, cl. 4. See note 5 supra. Cf. Cleveland v. United States, 323 U.S. 329 (1945) (federal statute exempted property of United States Housing Au- 
Other courts, reasoning that taxes levied against the buyer at a liquidation sale rather than the trustee are irrelevant to the court process, have upheld these taxes without reliance on the statute. ${ }^{7}$

A recent Ninth Circuit decision refused to test a state use tax by the identity of the party who suffered either its legal incidence or ultimate effect. In California State Bd. of Equalization v. Goggin, the state was enjoined from holding a trustee in bankruptcy liable for failure to collect the use tax due from a purchaser at a liquidation sale. ${ }^{8}$ The California statute levied the tax upon the purchaser and merely designated the seller a collection agent. ${ }^{9}$ Finding the legal incidence of use or sales taxes irrelevant, the court concluded that they are in fact paid by the buyer. ${ }^{10}$ Nevertheless, the waiver statute was held inapplicable and the tax declared invalid as a burden on the liquidation process. ${ }^{11}$ Presumably, this burden lay in the inconvenience which collection caused the trustee. ${ }^{12}$

thority from state, county and municipal taxation) ; Pittman v. HOLC, 308 U.S. 21 (1939) (state mortgage tax inapplicable to a federal instrumentality) ; McCulloch v. Maryland, 17 U.S. (4 Wheat.) 159 (1819) (absolute prohibition of taxation of one sovereign by another). But see notes 45, 47 infra and accompanying text; text at notes $42-44$ infra.

7. See In re Leavy, 85 F.2d 25 (2d Cir. 1936) (municipal sales tax); Jenks v. State, 188 Wash. 472, 63 P.2d 369 (1936) (state conveyance tax). One state court has viewed the tax as imposed upon the sale, rather than upon either buyer or seller. See Bird \& Jex Co. v. Anderson Motor Co., 92 Utah 493, 69 P.2d 510 (1937).

8. 245 F.2d 44 (9th Cir.), cert. denied, 353 U.S. 961 (1957). The trustee had conducted the bankrupt's business for seven years and had paid state sales and use taxes during that period. Id. at 47.

9. 2 CAL. Rev. \& TAX Code ANn. $\$ \S 6005,6015,6201,6203$ (Deering Supp. 1957): $\S 6005$ : “'Person' includes . . . trustee, trustee in bankruptcy . . . ."

§ 6015: “'Retailer' includes:

"(a) Every seller who makes any retail sale or sales of tangible personal property ....

"(b) Every person engaged in the business of making sales for storage, use, or other consumption...."

$\$ 6201$ : "An excise tax is hereby imposed on the storage, use, or other consumption in this State of tangible personal property ...."

$\S 6203$ : "Every retailer ... making sales of tangible personal property for storage, use, or other consumption in this State ... shall, at the time of making the sales, or, if the storage, use, or other consumption of the tangible personal property is not then taxable hereunder, at the time the storage, use, or other consumption becomes taxable, collect the tax from the purchaser...."

See Sutter Packing Co. v. State Bd. of Equalization, 139 Cal. App. 2d 889, 294 P.2d 1083 (1956) (private liquidator subject to sales tax in California); Market St. Ry. v. California State Bd. of Equalization, 137 Cal. App. 2d 87, 290 P.2d 20 (1955) (same).

10. 245 F.2d at 45 . The court did not support this conclusion with either analysis or authority.

11. Id. at 46 .

12. Id. at 45 . The court could not have condemned the tax because it precluded full realization by the bankrupt's estate, since it assumed that the buyer at the liquidation sale inevitably absorbed the tax. See note 11 supra and accompanying text. Therefore, the only conceivable burden imposed on the bankruptcy process was the state requirement that the seller collect the tax. 
Contrary to the conclusion in Goggin, a sales or use tax levied upon bankruptcy liquidations is borne by the trustee as seller. ${ }^{13}$ Price is determined by the interaction of supply and demand. ${ }^{14}$ By adjusting supply, the seller in a unique market can evoke a rise in price enabling him to shift some measure of a tax burden to the buyer. ${ }^{15}$ The risks, real or assumed, associated with the purchase of liquidation goods sufficiently distinguish such goods from their counterparts on the ordinary market to make liquidation sales unique. ${ }^{16}$ Nevertheless, the trustee cannot mitigate the effect of a tax by manipulating supply; he is under a duty to liquidate the entire bankrupt estate. ${ }^{17}$ And while judicial rejection of a liquidation sale would obviously alter the quantity involved, court confirmation, when required or sought, is geared to the price offered by the buyer rather than the value to be received by the trustee. ${ }^{18}$ Accordingly, just as the existence of a tax does not give rise to a price increase in the original

13. Designed to counteract avoidance of the sales tax, the California use tax is levied against buyers who purchase as retailers not subject to a sales tax and subsequently retain the goods as consumers. 2 CAI. Rev. \& TAX CodE ANn. $\$ 6203$ (Deering Supp. 1957), note 9 supra. Since the tax is occasioned by the transformation of a retail into a consumer use, it is not imposed at the time of sale. However, in determining the price they are willing to pay, retailers will most likely consider their subsequent duty to collect a tax, from the consumer if they resell or from themselves if they become consumers. In the former event, they will not be able to shift the sales tax burden. Resale will take place in the ordinary, not a unique, market.

14. Samuelson, Economics $367-78$ (3d ed. 1955).

15. Cf. id. at $382-\$ 3$.

16. Many personal rights of the bankrupt do not pass to the trustee with the property. A buyer cannot inspect books or ledgers and may not know precisely what rights he has purchased. Maclachlan, Bankruptcy 349 (1956). A purchaser may find his property subject to liens, since the bankruptcy court might not exercise its power to sell free of liens. See 4 Collier, Bankruptcy $\{$ 70.99, at 1598 (14th ed. 1942); Maclachlan, BANKRUPTCY 351 (1956). Sales are always uncertain, for the court may refuse to confirm. Thus, the position of a purchaser is precarious, since the sale immediately binds him but leaves the court with discretionary power to release the trustee from his contractual obligation. 4 CollIER, Bankruptcy $\{70.98$, at 1562-63, 1575 (14th ed. 1942). Finally, in the absence of specific warranties, the rule of caveat emptor applies. 4 CollIER, BANKRUPTCY If 70.98, at 1588 (14th ed. 1942).

17. The assets of the bankrupt's estate may be sold in bulk or in lots. 4 Collrer, BanKRuPTCY If 70.97, at 1556 (14th ed. 1942). But the total assets must be sold. See Bankruptcy Act $\$ 2 \mathrm{a}(7), 30$ SтAт. 546 (1898), as amended, 11 U.S.C. \$ 11(a) (7) (1952). But cf. Maclachlan, BankRuptcy 348 (1956), suggesting that in "the most unusual circumstances," the court "might conceivably" allow a distribution in kind.

To mitigate the effect of a sales tax, the seller must be able to reduce supply or to sell his goods in a market where they will not be subject to a tax. Since the trustee must sell all his goods and since the sales tax is uniform in application, neither course is available to the trustee. Accordingly, he must absorb the tax. SAMsuedson, Economics 391-92 (3d ed. '1955).

18. Bankruptcy Act $\S 70 f, 30$ STAT. 566 (1898), as amended, 11 U.S.C. $\S 110(f)$ (1952), requires court confirmation to sell property for less than $75 \%$ of its appraised value. See 4 Collier, Bankruptcy If 70.98, at 1562-63 (14th ed. 1942), observing that the statute requires confirmation whenever practicable, and MACLACHLAN, BANKRUPTCY 348 (1956), stating that court considers the gross sales price in fixing appraisal value. 
transaction, it will not constitute ground for dishonoring the sale. Although the trustee must thus absorb a sales or use tax, bankruptcy court process is not necessarily burdened. The ultimate economic burden falls on the unsecured creditors, ${ }^{19}$ who also bear the burden of collection if the trustee is an agent of the bankrupt's estate; and they, unlike the court, have no claim to constitutional immunity.

The Ninth Circuit's assumption that the trustee is primarily a representative of the bankruptcy court rather than of the unsecured creditors is questionable. ${ }^{20}$ The trustee is elected by the creditors, and only upon their failure to nominate a party meeting the standards of the act can he be appointed by the court. $^{21}$ His salary is paid by the estate, ${ }^{22}$ unlike referees and other court officers, he is not entitled to federal retirement benefits. ${ }^{23}$ While bankruptcy referees formerly were also compensated on a fee basis by the estate, ${ }^{24}$ Congress termed such a system objectionable when applied to public offices and granted the referees a salary to be paid from the federal treasury. ${ }^{25}$ The compensation of trustees was not changed $;^{26}$ Congress presumably did not consider

19. See Bankruptcy Act $\S 64 a(1$ ), 30 STAT. 563 (1898), as amended, 11 U.S.C. $\S 104$ (a) (1) (1952) (administrative expenses paid from estate as first priority). Administrative expenses are those incurred in preserving the estate and reducing it to liquid form for distribution to creditors. Taxes incurred in so doing are administrative expenses. See Missouri v. Gleick, 135 F.2d 134 (8th Cir. 1943) ; 3 Collmer, Bankruptcy $\uparrow 64.106$ (14th ed. 1956); MacLachlan, BankRuptCy 146 (1956).

To the extent $\$ 67 \mathrm{c}$ subordinates statutory liens and liens of distress for rent on personal property, the burden will also fall on "secured" creditors. See Bankruptcy Act $\$ 67 \mathrm{c}$, 30 STAT. 564 (1898), as amended, 11. U.S.C. $\$ 107$ (c) (1952).

20. But see Vass v. Conron Bros. Co., 59 F.2d 969 (2d Cir. 1932) ; Pearson v. Higgins, 34 F.2d 27 (9th Cir. 1929); Wurzel, Taxation During Bankruptcy Liquidation, 55 Harv. L. Rev. 1141, 1145 (1942) ; Note, Bankrnptcy Sale as a Judicial Sale Free From Taxation, $1 \mathrm{~J}$. PUB. L. 504,505 (1952). The only reason advanced by these authorities is that the trustee acts under the court's supervision. See also Bankruptcy Act $\$ 72,32$ STAT. 800 (1903), as amended, 11 U.S.C. $\$ 112$ (1952), entitled "Limitation of compensation of officers of court," which includes trustees within its terms. The description "officers" is probably here utilized merely to outline those persons whose compensation is subject to court review and approval.

21. Bankruptcy Act $\$ 44 a, 30$ STAT. 557 (1898), as amended, 11 U.S.C. $\$ 72$ (a) (1952).

22. See Bankruptcy Act $\$ 48 c, 30$ STAT. 557 (1898), as amended, 11 U.S.C. $\$ 76$ (c) (1952), as amended, 11 U.S.C. $\& 76$ (c) (Supp. IV, 1957).

23. See Bankruptcy Act $\S 40$ d, 60 Stat. 328 (1946), 11 U.S.C. § 68(d) (1952) (extension of retirement benefits to referees) ; H.R. REP. No. 1037, 79th Cong., 1st Sess. 7 (1945) ; S. REP. No. 959, 79th Cong., $2 \mathrm{~d}$ Sess. 7 (1946).

24. See 30 Stat. 556 (1898), as amended, 32 Stat. 799 (1903), as amended, 52 Stat. 859 (1938) ; 2 Collier, BankRUPTCY if 40.01 (14th ed. 1956).

25. Bankruptcy Act $\S 40 c(4), 60$ Star. 327 (1946), 11 U.S.C. $\S 68$ (c) (4) (1952); H.R. REP. No. 1037, 79th Cong., 1st Sess. 1 (1945) ; S. Rep. No. 959, 79th Cong., 2d Sess. 2 (1946). See also Bankruptcy Act $\& 62 a(4), 60$ STAT. 330 (1946), 11 U.S.C. $\S 102$ (a) (4) (1952) (extension of the franking privilege to referees).

26. H.R. Rep. No. 1275, 84th Cong., 2d Sess. 1, 2 (1956) ; see Bankruptcy Act § 48c, 30 STAT. 557 (1898), as amended, 11 U.S.C. $\$ 76$ (c) (1952), as amended, 11 U.S.C. $\$ 76$ (c) (Supp. IV, 1957). 
them public officers. ${ }^{27}$ Admittedly, the bankruptcy court exercises significant controls over the trustee. ${ }^{28}$ But they do not essentially differ from those employed by equity courts over fiduciaries in general. ${ }^{29}$

Even if the trustee is primarily an agent of the bankruptcy court, however, his conduct of liquidation sales seems within the federal waiver. ${ }^{30}$ The taxes encompassed by the waiver are those which would be applicable if a business operated by a federal agent were instead managed by an individual. ${ }^{31}$ The California use tax is regularly levied against such individually conducted liquidations. ${ }^{32}$ Moreover, case law outside the Ninth Circuit has consistently characterized liquidation as within the conduct of a business. ${ }^{33}$ Nevertheless, because liquidations embrace the sale of fixtures as well as inventory, Goggin distinguished them from business operations and held the waiver inapplicable. ${ }^{34}$ Admittedly, the language of the statute permits such an interpretation; for operating and liquidating a business may be activities of different scope and purpose. ${ }^{35}$ But the present statute succeeds a similar provision which express-

27. Cf. Missouri v. Gleick, 135 F.2d 134, 136 (Sth Cir. 1943) (only those instrumentalities paid from federal treasury can be deemed agents of federal government).

28. Bankruptcy Act $\$ 2 \mathrm{a}(7), 30$ STAr. 546 (1898), as amended, 11 U.S.C. $\$ 11$ (a) (7) (1952) (court to supervise collection and liquidation of bankrupt's estate); id. $\S 47,30$ SтAт. 557 (1898), as amended, 11 U.S.C. $\$ 75$ (1952) (trustee collects and liquidates property under court supervision, deposits money at designated depository, submits accounting, furnishes information and investigates claims); $i d . \S 48 \mathrm{c}, 30$ StAт. 557 (1898), as amended, 11 U.S.C. $\$ 76$ (c) (1952), as amended, 11 U.S.C. $\$ 76$ (c) (Supp. IV, 1957) (trustee's fee subject to court approval).

29. 2 Scorr, Trusts $\$ 164$ (2d ed. 1956) (trustee's duties determined by courts of equity) ; 2 id. $\S 172$ (duty of accounting) ; 2 id. $\$ 173$ (duty to furnish information); 2 id. $\S 176$ (duty to use reasonable care to preserve the trust property) ; 2 id. $\S 177$ (duty to investigate and enforce claims) $; 2 \mathrm{id} . \$ 180$ (duty to deposit money in a safe depository). Compare these duties with those of the bankruptcy trustee, note 28 supra.

30. See 28 U.S.C. $\$ 960$ (1952), note 4 supra.

31. See $i b i d$.

32. See note 9 supra.

33. See Missouri v. Gleick, 135 F.2d 134 (8th Cir. 1943); In re Loehr, 98 F. Supp. 402 (E.D. Wis. 1950) ; In re Mid America Co., 31 F. Supp. 601, 606 (S.D. Ill. 1939).

34. 245 F.2d at 48.

35. See California State Bd. of Equalization v. Goggin, 191 F.2d 726 (9th Cir. 1951); State Bd. of Equalization v. Boteler, 131 F.2d 386 (9th Cir. 1942) ; In re West Coast Cabinet Works, Inc., 92 F. Supp. 636, 660 (S.D. Cal. 1950); In re Owl Drug Co., 21 F. Supp. 907 (D. Nev. 1937). But see Missouri v. Gleick, 135 F.2d 134, 136 (8th Cir. 1943) : "The phrase 'conduct any business' should not receive a narrow and restricted interpretation, but should be construed to include any activity or operation in connection with the handling and management of the bankrupt estate."

U.S. Treas. Reg. $\$ 39.52-2$ (1956) specifically states: "Receivers, trustees in dissolution, trustees in bankruptcy, and assignees, operating the property or business of corporations, must make returns of income for such corporations. If a receiver has full custody of and control over the business or property of a corporation, he shall be deemed to be operating such business or property within the meaning of section 52 , whether he is engaged in carrying on the business for which the corporation was organized or only in marshaling, selling, and disposing of its assets for purposes of liquidation." See 3 CollIER, 
ly included liquidations, ${ }^{36}$ and the reviser's note indicates that the new law was not intended to make substantial changes in the old. ${ }^{37}$ Consequently, the present omission of liquidations can be ascribed to an attempt to recite in generic terms the particulars of the prior law. Furthermore, to reconcile local interest in raising revenue with the aim of freeing the federal government from substantial local interference, Supreme Court decisions commencing with Graves v. New York ex rel. O'Keefe ${ }^{38}$ have, without exception, directed liberal construction of federal waivers in favor of state taxing authorities. ${ }^{39}$ The federal waiver applicable to the conduct of businesses under the authority of United States courts is an unequivocal declaration of congressional policy. ${ }^{40}$ If its scope is ambiguous, Graves dictates a construction which includes bankruptcy liquidations. ${ }^{41}$

Case law suggests that a sales or use tax should be upheld even in the absence of an applicable federal waiver. The immunity of one sovereign from taxation by another originated in the belief that the taxing power is necessarily destructive. ${ }^{42}$ This rationale has been repudiated, ${ }^{43}$ and Graves indicates that only

BANKRUPTCY If 62.14, at 1511 (14th ed. 1956) (this administrative interpretation has been sanctioned by tacit re-enactment); Wurzel, supra note 20, at 1170-71.

In the Matter of F. P. Newport Corp., 144 F. Supp. 507 (S.D. Cal. 1956), a district court case following the Ninth Circuit distinction between liquidating and conducting a business, holds liquidation proceeds not subject to federal income tax. The decision appears to have overlooked the treasury regulation.

36. See 48 Stat. 993 (1934) (amended by 62 Star. 927 (1948), 28 U.S.C. $\$ 960$ (1952)) : "That any receiver, liquidator, referee, trustee, or other officers or agents appointed by any United States court who is authorized by said court to conduct any business, or who does conduct any business, shall, from and after the enactment of this Act, be subject to all State and local taxes applicable to such business the same as if such business were conducted by an individual or corporation ...." (Emphasis added.) See also notes 4, 10 supra; Missouri v. Gleick, supra note 35, at 136-37 (8th Cir. 1943) (holding that the statute covers liquidation of a business) ; In re Mid America Co., $31 \mathrm{~F}$. Supp. 601, 606 (S.D. I11. 1939) (same).

37. See Reviser's Note, 28 U.S.C. $\$ 960$ (1952) ; Moore, Judicial Code Commentary If $0.03(44)$, at $297-98$ (1949).

38. 306 U.S. 466 (1939).

39. See Oklahoma Tax Comm'n v. United States, 319 U.S. 598 (1943) ; Tradesmens Nat'1 Bank v. Oklahoma Tax Comm'n, 309 U.S. 560 (1940) ; Corwin, Tee Constitution and What It Means Today 179 (11th ed. 1954).

40. See note 4 supra; 3 Collier, Bankruptcy $\{$ 62.14, at 1516-17 (14th ed. 1956); Wurzel, supra note 20 , at 1168 .

41. 306 U.S. at $483-87$.

42. MícCulloch v. Maryland, 17 U.S. (4 Wheat.) 316, 431 (1819). "[T]he power to tas involves the power to destroy; ... the power to destroy may defeat and render useless the power to create...."

43. See cases cited note 45 infra. Australia and Canada, facing similar problems of federalism, have narrowly restricted intergovernmental immunities. Compare D'Emden v. Pedder, 1 Commw. L.R. 91 (Austr. 1904) (adopting the rigid reasoning of $\mathrm{McCulloch} v$. Maryland and holding state receipt tax inapplicable to salary of federal officer although interference with constitutional power of Commonwealth slight), with West v. Commissioner, 56 Commw. L.R. 657 (Austr. 1937) (state income tax on pension of federal officials 
taxes which can be so manipulated should be invalidated. ${ }^{44}$ Absent discriminatory application against sellers and buyers at liquidation sales, a sales or use tax should not seriously impede the federal bankruptcy process. A general tax which significantly interfered with the unsecured creditors' ultimate recovery would disrupt the state's entire business community-a result local legislators are unlikely to favor. Moreover, the Supreme Court has regularly upheld state levies which imposed only insubstantial burdens on federal instrumentalities. ${ }^{45}$ If the trustee suffers any burden, it does not exceed the duty of collection. ${ }^{46}$ A sales tax may be collected by merely allocating part of the purchase price to the state at the time of the sale. And while collection of a use tax might be more arduous, it too falls within the purview of Supreme Court decisions finding burdens insubstantial.47

valid). See Amalgamated Soc'y of Engineers v. Adelaide S.S. Co., 28 Commw. L.R. 129 (Austr. 1920) (abandoning blanket prohibition of D'Emden v. Pedder, supra). See also Dixon, Mr. Justice Frankfurter-A Tribute From Australia, 67 Y ALE L.J. 179, 180 (1957).

Canada has long opposed implied intergovernmental immunities. See Abbot v. City of St. John, 40 Can. Sup. Ct. 597 (1908) (validating provincial income tax on dominion official's salary); Caron v. The King, [1924] A.C. 999 (converse; on appeal from Canadian courts).

44. 306 U.S. at 480.

45. Oklahoma Tax Comm'n v. Texas Co., 336 U.S. 342 (1949) (state excise tax on lessees of mineral rights of restricted Indian lands); Graves v. New York ex rel. O'Keefe, 306 U.S. 466 (1939) (state income tax on employees of HOLC) ; James v. Dravo Contracting Co., 302 U.S. 134 (1937) (state gross receipts tax on contractor building dams for federal government) ; Indian Territory Illuminating Oil Co. v. Board of Equalization, 288 U.S. 325 (1933) (state ad valorem tax on lessee of restricted Indian lands); Fox Film Corp. v. Doyal, 286 U.S. 123 (1932) (state gross receipts tax on copyright royalties); National Bank v. Commonwealth, 76 U.S. (9 Wall.) 353 (1869) (state capital stock tax on national bank); Western Lithograph Co. v. State Bd. of Equalization, 11. Cal. 2d 156, 78 P.2d 731 (1938) (state sales tax valid although paid by national bank); Bedford v. Colorado Nat'l Bank, 104 Colo. 311, 91 P.2d 469 (1939), aff'd per curian, 105 Colo. 373, 98 P.2d 1120, aff'd, 310 U.S. 41 (1940) (state service tax on national banks). For valid federal taxes levied against state instrumentalities, see Helvering v. Gerhardt, 304 U.S. 405 (1938) (federal income tax on employees of Port of New York Authority); Metcalf \& Eddy v. Mitchell, 269 U.S. 514 (1926) (federal income tax on state engineers). For discussion of the doctrine of "insubstantial burden," see Wurzel, supra note 20, at 1167; Note, Bankruptcy Sale as a Judicial Sale Free From Taxation, 1 J. Pub. L. 504, 505 (1952). For examples of taxes substantially burdening federal instrumentalities and therefore held invalid, see cases cited note 6 supra.

46. Ordinarily, the seller is not required to collect a use tax. Se'e, e.g., Fla. Stat. ANN. \$212.06(1), (2) (d) (Supp. 1956); GA. Code ANn. \$ 92-3404a(4) (Supp. 1955).

Seven states join California in imposing this requirement. Ala. CODE ANN. tit. 51, § 791 (Supp. 1955) ; Colo. Rev. Stat. Anv. § 138-6-35(2) (Supp. 1955) ; Conn. Gen. Stat. \$ 2095(3) (1949); MD. ANN. Code art. 81, \$ 371 (1951); 3 Nev. Rev. Stat. c. 372.195 (1956) ; R.I. Gen. Laws c. 1887, \$ 23 (1947); S.C. CoDE § 65-1427 (Supp. 1955).

47. See West v. Oklahoma Tax Comm'n, 334 U.S. 717 (1948) (possibility that state estate tax would force federal government to conduct litigation ruled insubstantial burden); National Bank v. Commonwealth, 76 U.S. (9 Wall.) 353, 362 (1869) (insubstantial burden one which would not seriously impair instrumentality's usefulness or capability to serve the government). 
Rather than suggesting invalidity, considerations of federalism militate in favor of allowing state sales and use taxation of bankruptcy liquidations. State governments, apprehensive of driving residents and industry from their borders, are hesitant to tax activities already burdened by significant federal levies. ${ }^{48}$ Thus deterred from raising revenue through income, estate and corporate taxation, they have in increasing measure relied on sales, use and property taxes. ${ }^{49}$ To the extent these means are unsuccessful, the states' ability to assume the myriad responsibilities entrusted to them without resort to federal aid and potential federal control is diminished. ${ }^{50}$ Taxation of liquidation sales can produce substantial revenue for the states. ${ }^{.1}$ Since such levies need not hamper federal activities, antiquated principles of sovereign immunity which undermine congressional and Supreme Court policy should not be permitted to make more complex the already difficult task of adjusting the roles of state and national government.

48. Due, The Nature and Structure of Sales Taxation, 9 VAND. L. Rev. 123, 131 (1956) ; see Pierce, The Place of Consumers' Excises in the Tat System, 8 Law \& ConTearp. Pros. 430, 438 (1941); Rice \& Estes, Sales and Use Taxes as Affected by Federal Governmental Immunity, 9 VAND. L. REv. 204, 222 (1956).

49. Sales and use taxes are the chief source of revenue for most state governments. Hellerstein, The Scope of the Sale Under Sale and Use Ta.r Acts, 11 TAx L. Kinv. 261 (1956). See Due, Sales Taxes; Three Different Types Prevail in Local Taxation Today, 7 J. Taxation 194 (1957). Due, supra note 48; Pierce, supra note 48, at 437. See also Peterson, The Los Angeles City Sales Tax Administration, 2 NAT'L TAx J. 232 (1949) (in Los Angeles, where the Goggin case originated, local revenue increased $670 \%$ the first year a sale's tax was introduced). Collected monthly, sales taxes diminish the need for reserve funds and loans, normally required between property tax collections. Id. at 246 . In addition, they do not threaten the disincentive effects characteristic of progressive income taxation. See Kaldor, AN Expenditure Tax 14, 140 (1955), discussed in Solo, Accumulation, Work Incentive, and the Expenditure Tax, 9 NATL TAX J. 283 (1956).

50. See Hellerstein, supra note 49; Pierce, supra note 48, at 433-34; Rice \& Estes, supra note 48 , at 222 .

The postwar European economic recovery, to a great extent based on sales taxation, reveals the potential of such levies. See Brabson, Analysis of Sales and Use Tax Exemptions-With Comment as to More Uniform Applications, 9 VAND. L. Rev. 294, 309 (1956).

For the extent to which sales and use taxes are utilized throughout the world, see Studenski, Characteristics, Developments and Present Status of Consumption Taxcs, 8 LAW \& CONTEMP. Prob. 417, 426-29 (1941).

51. See Judiclal Conference Ann. Rep. 238, table F5 (1955). At the normal 3\% sales tax rate in 1955 , the Goggin approach would deny the states approximately $\$ 1,250,000$ in revenue. See ibid. Bankruptcy cases have increased approximately fivefold in the past decade, see $i d$. at 130 , chart 15 , and reached a record level in the court year ending September 30, 1957, N.Y. Times, Nov. 25. 1957, p. 21, col. 3. 